\title{
है
}

INDO GLOBAL JOURNAL OF

PHARMACEUTICAL SCIENCES

ISSN 2249- 1023

\section{Characterization of Biosurfactant from Bacillus Isolates as Antifungal Agent}

\author{
Pawan Kumar ${ }^{1}$, Rani Sharma ${ }^{2}$, Archana Gajbhiye ${ }^{* 2}$ \\ ${ }^{1}$ Panacea Biotech Ltd., B-1, Extn. 24-25, Mohan Co-operative Industrial Estate, Mathura Road, New Delhi-110044 \\ ${ }^{2}$ Department of Biotechnology, Sir Padampat Singhania University, Bhatewar, Udaipur-313601, India
}

\begin{abstract}
Address for Correspondance

Archana

Gajbhiye,

Archana.yg@gm

ail.com
\end{abstract}

\section{Keywords}

Biosurfactant;

Antifungal

Activity;

Bacillus; $R$.

oryzae-sativae;

F. solani.

\begin{abstract}
Use of green compounds to achieve the sustainable agriculture is the present necessity. Biosurfactants are one of the green compounds reported to be produced by bacteria, yeasts, and fungi which are considered to be less toxic and eco-friendly with extensive applications in pharmaceutical, cosmetics, and food industries. Bacillus group is one of the examples of biosurfactant producers. In the present study soil isolates of Bacillus species were screened for the production of biosurfactant by oil spread assay. The activity was found positive in three isolates which were assayed for antifungal activity against the phytopathogens $R$. oryzae-sativae and $F$. solani. The biocontrol activity was observed in both extracellular and the homogenized biomass fractions of B. subtilis BP-9, B. subtilis BP-13 and Bacillus isolate PRIS-1. Different methods as acid precipitation, organic solvent extraction and salting out by ammonium sulfate were used for isolation of biosurfactant lipopeptides from the extracellular fractions of B. subtilis BP-9, B. subtilis BP-13 and Bacillus species PRIS-1. The antifungal as well as biosurfactant property was confirmed in the acid precipitated fraction of Bacillus isolate PRIS-1. The compound was identified as a high molecular weight protein by SDSPAGE with approximate size of 100kD.@ 2015 iGlobal Research and Publishing Foundation. All rights reserved.
\end{abstract}

NOTE: Full length manuscript of Kumar et al. Characterization of Biosurfactant from Bacillus Isolates as Antifungal Agent. 2014; 4(3): 166.

\section{INTRODUCTION}

Biosurfactants are surface-active compounds produced by living organisms. Biosurfactants derived mainly from microorganisms have attracted much attention because of advantageous characteristics such as structural diversity, low toxicity, higher biodegradability, better environmental compatibility, higher substrate selectivity, and lower critical micelle concentration (CMC) $[1,2,3,4]$. There are different types of biosurfactant stated based on their physico-chemical properties as glycolipids, lipopeptides, neutral lipids, phospholipids, fatty acids, and polymeric $[5,6,7,8,9]$. It has potential to be applied in pharmaceutical, cosmetics, petroleum, and food industries $[6,10,11,12,13]$, used as bioremediation agent for treatment of soil and water [14] and used for removal of hydrocarbons as well as heavy metals [15]. In addition, it has demonstrated antifungal, antiviral, antitumor, insecticidal, and anti-mycoplasma activities. Surfactants are also reported to inhibit the aflatoxin production by Aspergillus sp. which infects crops [16]. Thus the surfactants (synthetic and biological) play diverse role in plant pathogen elimination directly or indirectly and at different processes related to agriculture. In view of sustainable development biosurfactant would provide a new hope to overcome the problem of loss of productivity in agricultural sector due to fungal diseases. Approx. \pm 0.2 million tons of surfactants are used in crop protection and agrochemical formulations[17].Biosurfactants from several microbes (i.e. Pseudomonas spp., Acinetobacter 


\section{Indo Global Journal of Pharmaceutical Sciences, 2015; 5(2): 117-123}

spp., Bacillus spp., and Candida spp.) have antimicrobial and antifungal activity against plant pathogens and therefore they are considered to a promising biocontrol agents for achieving sustainable agriculture [18,19,20]. Considering the antagonistic and antifungal properties of Bacillus spppresent study is performed for screening of Bacillus isolates from soil for production of biosurfactant and its characterization for antifungal property.

\section{MATERIALS \& METHODS}

\section{Bacterial and fungal cultures}

In the present study six soil isolates of Bacillus species viz. $B$. subtilis $\mathrm{BP}-1$, B. subtilis $\mathrm{BP}-2, B$. subtilis $\mathrm{BP}-5, B$. subtilis BP-9, B. subtilis BP-13 and Bacillus isolate PRIS1 were used. These cultures were obtained from Department of Biotechnology, Sir Padampat Singhania University, Udaipur. The bacterial cultures were maintained on nutrient agar slants. The fungal cultures of Rhizoctonia oryzae-sativae (MTCC code-2162)and Fusarium solani (MTCC code 2671) were obtained from MTCC, Chandigarh (India) and maintained on Potato Dextrose Agar (PDA) slants. Both the cultures were stored in refrigerator at temperature $7^{\circ} \mathrm{C} \pm 2$ with regular sub-culturing at an interval of 1 month.

\section{Biosurfactant activity}

Biosurfactant assay was performed with the culture broths of the Bacillus isolates. To determine the presence of a lipoprotein by oil displacement method $10 \mu \mathrm{l}$ of crude oil was dropped over the surface $40 \mathrm{ml}$ of distilled water in a petri dish to form a thin oil layer and onto it $10 \mu \mathrm{l}$ of extract was gently dropped and checked for the formation of a clear zone [21]. The positive cultures were screened and further used for detection of antifungal property.

\section{Antifungal activity of Bacillus isolates}

The bacterial cultures grown in nutrient broth medium at $37^{\circ} \mathrm{C}$ for $48 \mathrm{~h}$ were used to detect the antagonistic activity against the phytopathogens $R$. oryzae-sativae and $F$. solani. A $5 \mathrm{~mm}$ diameter mycelial disc of fungi was placed in the center and bacterial isolate were spot inoculated at $3 \mathrm{~cm}$ distance from disc on a potato dextrose agar (PDA) [22]. The zone of inhibition was observed after every $24 \mathrm{~h}$ of incubation at $28^{\circ} \mathrm{C}$.

\section{Detection of antifungal property in extracellular fraction}

The selected positive cultures were further used for detection of the extracellular production of the antifungal active compound. The supernatant was separated from the biomass by centrifugation at $10000 \mathrm{rpm}$ for $15 \mathrm{~min}$. The culture biomass was suspended in sterile distilled water and homogenized to release intracellular components [23]. The antifungal assay with intracellular (homogenized biomass) and extracellular (the supernatant) fractions was carried out on $1 \%$ starch agar. The mycelia was inoculated in the center of the petri plate and allowed to grow and after $48 \mathrm{~h}$, wells $(0.65 \mathrm{~cm}$ in diameter) were created at a distance of $0.5 \mathrm{~cm}$ away from the rim of the mycelial colony. Each well was filled with $30 \mu \mathrm{l}$ of the sample and the plates were incubated at $28^{\circ} \mathrm{C}$ until mycelia growth had developed in the control plate without any sample [24].

\section{Extraction of the active component}

Overnight grown cultures of B. subtilis BP-9, B. subtilis BP-13 and Bacillus isolate PRIS-1 in nutrient broth at $37^{\circ} \mathrm{C}$ were used for extraction of active compound. To extract the extracellular products the biomass was separated by centrifugation at 10000rpm for $15 \mathrm{~min}$ at $4^{\circ} \mathrm{C}$. The extraction was performed by three methods viz. organic solvent extraction, ammonium sulphate precipitation and acid precipitation.

\section{Extraction with organic solvent}

Culture supernatant was stirred vigorously for $20 \mathrm{~min}$ with organic solvents, chloroform- methanol $(2: 1, \mathrm{v} / \mathrm{v})$ in $1: 1(\mathrm{v} / \mathrm{v})$ ratio [25]. The solvent phase was evaporated and the sediments were dissolved in buffer $\left(0.1 \mathrm{~mol}^{-1}\right.$ Tris, $\mathrm{pH} 7.0)$.

\section{Ammonium sulphate precipitation method}

Proteins were precipitated by the slow addition of ammonium sulphate to the supernatant fluid up to $40 \%$ saturation, and stirred at $7^{\circ} \mathrm{C}$ for $24 \mathrm{~h}$ [26]. The precipitate was separated by centrifugation at $4^{\circ} \mathrm{C}$ and $10000 \mathrm{rpm}$ for $20 \mathrm{~min}$. The pellet was re-suspended in buffer $\left(0.1 \mathrm{~mol} \mathrm{l}^{-1}\right.$

${ }^{1}$ Tris buffer, $\mathrm{pH} 7$ ).

\section{Acid precipitation method}

The culture supernatant was acidified by adding $2 \mathrm{~N} \mathrm{HCl}$ to obtain a final $\mathrm{pH}$ of 2.0 and stored overnight at $4{ }^{\circ} \mathrm{C}$ for $24 \mathrm{~h}$ [27]. The acid precipitate was collected by 


\section{Indo Global Journal of Pharmaceutical Sciences, 2015; 5(2): 117-123}

centrifugation at $12,000 \mathrm{rpm}$ for $20 \mathrm{~min}$ at $4^{\circ} \mathrm{C}$ and dissolved in a methanol.

\section{Analysis of extracts}

All these extracts were tested for the presence of the active component by the antifungal assay method as mentioned above [24]. The plates were incubated for $72 \mathrm{~h}$ at $27^{\circ} \mathrm{C}$ and the inhibitory activity of each extract was expressed as the percent growth inhibition, compared to the control. The extract was also analyzed for biosurfactant activity by oil spread assay using $10 \mu \mathrm{l}$ of extract.

\section{Analysis of extracts by SDS PAGE}

The extracts were analyzed for presence of protein by performing discontinuous SDS-PAGE using 4\% stacking gel and $12 \%$ resolving gel. Electrophoresis was performed at $100 \mathrm{~V}$ using tris-glycine buffer.

\section{RESULTS \& DISCUSSION}

All six Bacillus cultures showed a clear zone formation in the oil spread assay and were considered positive for biosurfactant activity. The maximum zone of clearance in oil spread assay was observed in Bacillus isolate PRIS-1 (Table 1). These cultures were further used for detection of the antifungal activity. Fungal growth inhibition was observed in five Bacillus isolates out of six cultures namely B. subtilisBP-2,B. subtilis BP-5,B. subtilisBP-9, B. subtilisBP-13 and Bacillus species PRIS-1.Amongst all the isolates $B$. subtilis BP-13 have shown the maximum inhibition of $14 \mathrm{~mm}$ against $F$. solani (Fig 1, Table 1) and least in B. subtilis BP-2, B. subtilis BP-5.
Furthermore for determining the intracellular and extracellular production of antifungal activities in the selected isolates; B. subtilis BP-9, B. subtilis BP-13 and Bacillus isolate PRIS-1, the antifungal assay was performed with the homogenized biomass pellet suspended in buffer (intracellular fraction) and the culture supernatant (extracellular fraction). The antifungal activity against both the phytopathogenic fungi was observed positive in both the fractions of the three Bacillus isolates. The maximum positive inhibitory activity was showed by Bacillus isolate PRIS-1 (Fig 2). These results confirmed a strong antifungal activity in Bacillus isolate PRIS-1 and presence of active component both as intracellular as well as extracellular.

The cultures grown in nutrient broth were used for the extraction of biosurfactant. The extract was obtained by three different methods viz. organic solvent extraction, salting out (ammonium sulfate precipitation) and acid precipitation methods. In the analysis for the presence of active antifungal component in the extracts, the positive activity was observed only in the extract obtained by acid precipitation method (Fig 2, Table2). No significant activity was observed in the other two extracts. The biosurfactant property of the active component in the purified extract was confirmed by oil displacement assay. The molecular characterization of the active components in the extracts was performed by SDS PAGE. The results showed a single band of protein approximately of $100 \mathrm{kDa}$ molecular weight in the Bacillus isolate PRIS-1 extract, which confirmed the active component as high molecular weight protein (Fig. 3)

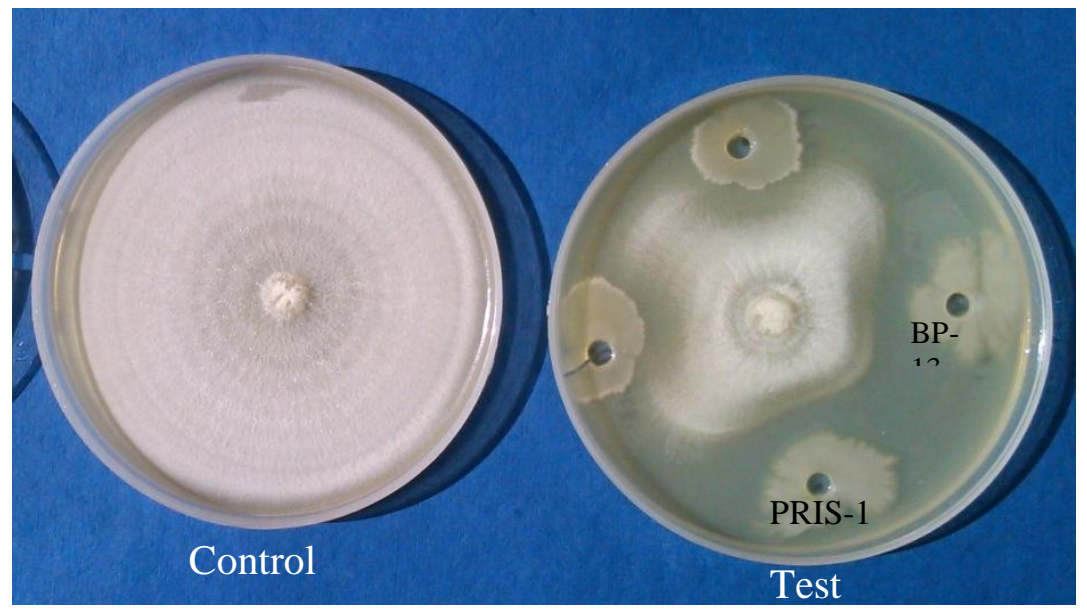

Fig. 1: Antagonism behavior shown by $B$. subtilis BP-13 and Bacillus isolate PRIS-1 in dual culture assay against $F$. solanicompared to the radial growth of $F$. solani in control plate. 
Indo Global Journal of Pharmaceutical Sciences, 2015; 5(2): 117-123
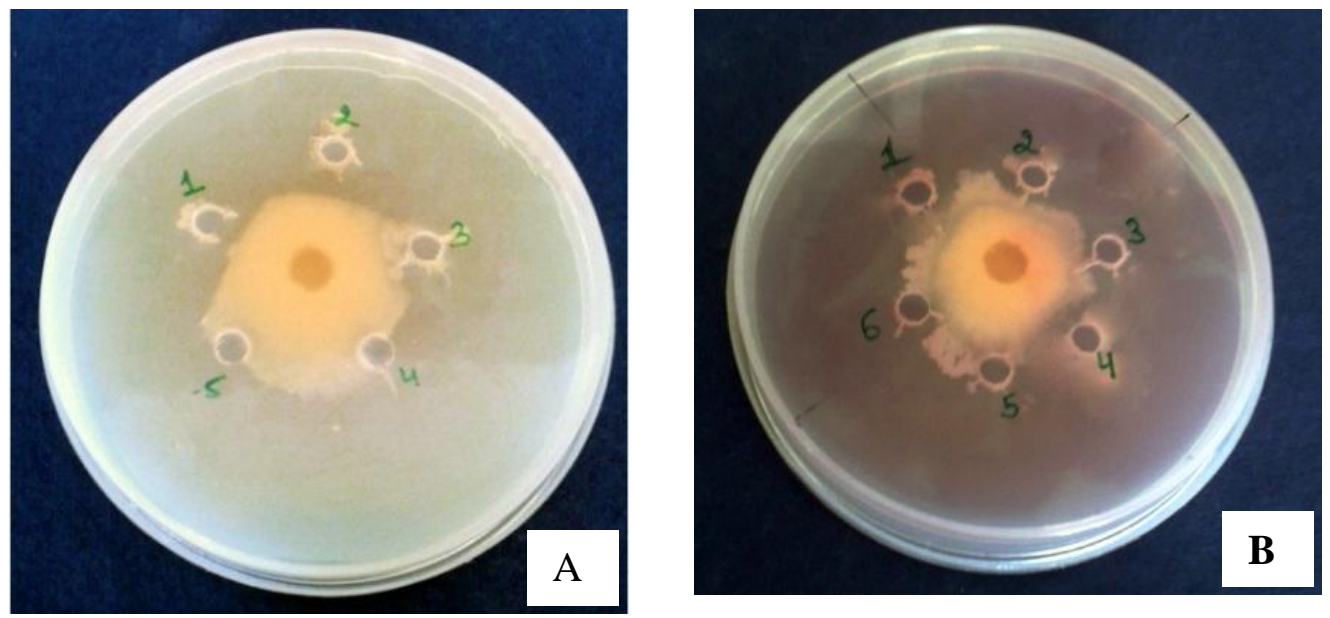

Fig. 2: Fungal growth inhibition of pattern.

A: Bacillus isolate PRIS-1 against $F$ solani;1 \& 2: Biosurfactant extract (acid precipitation); 3: Cell Biomass homogenate, 4: Organic solvent extract; 5: Control.

B: Bacillus isolate PRIS-1 against R. oryzae; 1: Culture supernatant; 2: Homogenized Cell biomass; 3 \& 4: Biosurfactant extract (acid precipitation); 5: Organic solvent extract; 6: Control.

It is very well known fact that Bacillus spp. are among the important soil inhabitant and are safe bacteria. This group of bacteria were instantly studied with regard to the production of bioactive compounds and have been extensively studied for their abilities for synthesizing a vast array of beneficial substances [28] and used as potential antimicrobial agents [29,30,31]. There were several reports on Bacillus potential as biological control agent against many common phytopathogens [32,33]. In the present study Bacillus Isolates have shown the in vitro antifungal activity in Bacillus isolates against Fusarium solani. Similar results were obtained by Sadfi et al. [34].

The anitmicrobial activity of Bacillus spp is attributed to production of HCN, siderophore, hydrolytic enzymes and antibiotics [35]. It is also likely that the most effective biological control strains act via multiple mechanisms. Antimicrobial activity of several biosurfactants has been reported in the literature for many different applications [36]. The most commonly isolated biosurfactants are glycolipids and lipopeptides. They include rhamnolipids released by Pseudomonas aeruginosa [37], sophorolipids from Candida sp. [38], as well as surfactin and iturin produced by Bacillus subtilis strains [39]. In the present study the bioactive compound produced by PRIS-1 having a biosurfactant activity has been identified with the ability to inhibit the mycelial growth. The compound was identified as protein by SDS PAGE -having a molecular weight of approximately $100 \mathrm{kDa}$. Two categories of biosurfactants were identified to be produced by Bacillus species, low molecular weight and high molecular weight [40]. In the present study the antifungal biosurfactant was found to be of high molecular weight of around 100KD and may be considered to be a lipopeptide.

It can be concluded that strains, Bacillus isolate PRIS-1, produced antagonistic fungal biosurfactant compound which might be lipopeptide in nature. In addition, it might be used in various industrial fields, including the food industry, clinics, cosmetics and specialty chemical industries, and for cleaning oil spills by bioremediation. Therefore, we expect that these lipopeptides may be useful in agriculture and various industries as biocontrol agents and biosurfactants, respectively, although further study is needed. 
Indo Global Journal of Pharmaceutical Sciences, 2015; 5(2): 117-123

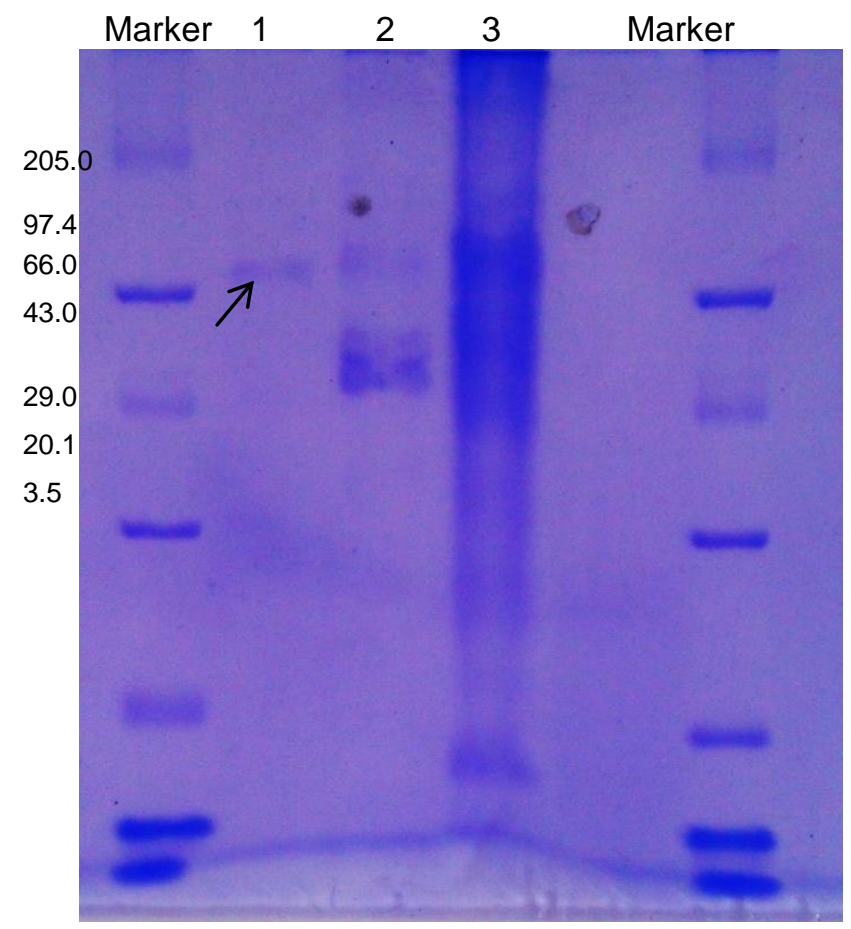

Fig. 3: SDS PAGE Pattern

Table 1: Comparative study of biosurfactant activity by oil displacement method and the antagonism pattern against the phytopathogenic fungi by Bacillus isolates in dual culture assay.

\begin{tabular}{|c|c|c|c|c|}
\hline \multirow{2}{*}{$\begin{array}{l}\text { Sr. } \\
\text { No. }\end{array}$} & \multirow[t]{2}{*}{ Isolates } & \multirow{2}{*}{$\begin{array}{l}\text { Biosurfacatnt activity by } \\
\text { Oil Displacement (clear } \\
\text { zone in } \mathbf{m m} \text { ) }\end{array}$} & \multicolumn{2}{|c|}{ Antifungal Activity Against } \\
\hline & & & Rhizoctonia oryzae & Fusarium solani \\
\hline 1. & Bacillus subtilis BP 1 & 25 & - & - \\
\hline 2. & Bacillus subtilis BP 2 & 35 & + & + \\
\hline 3. & Bacillus subtilis BP 5 & 60 & + & + \\
\hline 4. & Bacillus subtilis BP 9 & 40 & ++ & ++ \\
\hline 5. & Bacillus subtilis BP 13 & 70 & ++ & ++ \\
\hline 6. & Bacillus isolate PRIS 1 & 80 & ++ & ++ \\
\hline
\end{tabular}

Table 2: Antifungal characteristic of extracts from different Bacillus isolates obtained by acid precipitation method.

\begin{tabular}{|c|c|c|c|c|c|}
\hline \multirow{2}{*}{$\begin{array}{l}\text { Sr. } \\
\text { No. }\end{array}$} & \multirow[t]{2}{*}{ Bacillus Isolates } & \multicolumn{2}{|c|}{ Against $F$. solani } & \multicolumn{2}{|c|}{ Against $R$. oryzae-sativae } \\
\hline & & $\begin{array}{l}\text { *Fungal Growth } \\
\text { diameter in test } \\
\text { (T) } \mathrm{mm}\end{array}$ & $\begin{array}{c}\text { \% Inhibition } \\
\frac{(\mathrm{C}-\mathrm{T}) \mathbf{x 1 0 0}}{\mathrm{C}}\end{array}$ & $\begin{array}{l}\text { *Fungal Growth } \\
\text { diameter in test } \\
\text { (T) } \mathrm{mm}\end{array}$ & $\begin{array}{c}\text { \% Inhibition } \\
\frac{(\mathrm{C}-\mathrm{T}) \times 100}{\mathrm{C}}\end{array}$ \\
\hline 1 & B. subtilis BP-9 & 35 & 44.44 & 58 & 3.3 \\
\hline 2 & B. subtilis $\mathrm{BP}-13$ & 31 & 50.79 & 50 & 16.6 \\
\hline 3 & Bacillus isolate PRIS -1 & 25 & 60.32 & 20 & 66.66 \\
\hline \multicolumn{6}{|c|}{$\begin{array}{l}\text { *Growth diameter of mycelium in direction of spot inoculated Bacillus culture. } \\
\text { Growth diameter of } F \text {. solani in control plate }(C)=63 \mathrm{~mm}\end{array}$} \\
\hline
\end{tabular}




\section{Indo Global Journal of Pharmaceutical Sciences, 2015; 5(2): 117-123}

\section{ACKNOWLEDGEMENTS}

The authors are thankful to Sir Padampat Singhania University, Udaipur for providing laboratory facility as well as financial assistant for present research work.

\section{REFERENCES}

1. Kim, H.S., Jeon, J.W., Kim, S.B., Oh, H.M., Kwon, T.J.,Yoon, B.D. Surface and physico-chemical properties of a glycolipid biosurfactant, mannosylerythritollipid, from Candida antarctica. Biotechnol. Lett., 2002; 24:1637-1641.

2. Wong, J.W.C., Fang, M., Zhao, Z., Xing, B. Effect of Surfactants on Solubilization and Degradation of Phenanthrene Under Thermophilic Conditions. J. Env. Quality., 2003; 33 (6): 2015-2025.

3. Pornsunthorntaweea, O., Wongpanita, P., Chavadeja, S., Abeb, M., Rujiravanita, R. Structural and physicochemical characterization of crude biosurfactant produced by Pseudomonas aeruginosa SP4 isolated from petroleumcontaminated soil. Biores. Technol., 2008; 99 (6): 15891595 .

4. Medrzycka, K., Hallmann, E., Pastewski, S. Evaluation of surfactant and biosurfactant mixture usefulness in oil removal from soil, based on physicochemical studies and flushing experiments. Environ. Prot. Eng., 2009; 35: 191205.

5. Amaral, PF., Coelho, MA., Marrucho, IM., Coutinho, JA. Biosurfactants from yeasts: characteristics, production and application. Adv Exp Med Biol., 2010;672:236-249.

6. Banat, IM., Franzetti, A., Gandolfi, I., Bestetti, G., Martinotti, MG., Fracchia, L., Smyth, TJ., Marchant, R. Microbial biosurfactants production, applications and future potential. Appl Micro boil Biotechnol., 2010; 87: 427-444.

7. Cameotra, SS., Makkar, RS., Kaur, J., Mehta, SK. Synthesis of biosurfactants and their advantages to microorganisms and mankind. Adv Exp Med Biol., 2010;672:261-280

8. Franzetti, A., Gandolfi, I., Bestetti, G., Smyth, TJP., Banat, IM. Production and applications of trehalose lipid biosurfactants. European J Lipid Sci Technol., 2010;112:617-627.

9. Pacwa-Plociniczak, M., Plaza, JA., Piotrowska-Seget, Z., Cameotra, SS. Environmental application of biosurfactants: Recent advances. Int. J. Mol. Sci., 2011; 12:633-654.

10. Rodrigues, L., Banat, I.M., Teixeira, J. and Oliveira, R. Biosurfactants: Potential applications in medicine. J Antimicrob Chemother, 2006; 57: 609-618.

11. Nitschke, M., Coasta, S.G. Biosurfactants in food industry. Trends Food Sci. Technol., 2007; 18:252-259.

12. Lourith, N., Kanlayavattanakul, M. Natural surfactants used in cosmetics: glycolipids. Int J Cosmet., 2009; 29: 225-261.

13. Das, P., Mukherjee, S., Sivapathasekaran, C., Sen, R. Microbial surfactants of marine origin: potentials and prospects. Adv Exp Med Biol., 2010;672:88-101.

14. Mulligan, C.N. Environmental applications for biosurfactants. Environ. Pollut., 2005; 133:183-198.

15. Sun, X., Wu, L., Luo, Y. Application of organic agents in remediation of heavy metals- contaminated soil. Ying Yong Sheng Tai XueBao., 2006;17:1123-1128.
16. Rodriguez, SB., Mahoney, NE. Inhibition of aflatoxin production by surfactants. Appl Environ Microbiol., 1994;60:106-110.

17. Deleu, M., Paquot, M. From renewable vegetables resources to microorganisms: new trends in surfactant. CR Chimie., 2004;7:641-646.

18. Zuber, P., Nakano, M.M., Marahiel, M.A. Peptide Antibiotics. In Bacillus subtilis and Other Gram-Positive Bacteria. Biochemistry, Physiology, and Molecular Genetics ed., 1993; 897-916.

19. Sadfi, N., Cherif, M., Fliss, I., Boudabbous, A., Antoun, H. Evaluation of Bacillus isolates from salty soils and Bacillus thuringiensis strains for the biocontrol of Fusarium dry rot of potato tubers. J. Plant. Pathol., 2001; 83: 101-118.

20. Gajbhiye, A., Rai, AR., Meshram, SU., Dongre, AB. Isolation, evaluation and characterization of Bacillus subtilis from cotton rhizospheric soil with biocontrol activity against Fusariumoxysporum. World J of Microbiology and Biotechnology, 2010; 26: 1187-1194.

21. Morikawa, M., Hirata, Y., Imanaka, T. A Study on the structure-function relationship of lipopeptides biosurfactants. Biochimica et Biophysica Acta, 2000; 1488: 211218.

22. Nielsen, M. N., Sorensen, J., Fels, J., Pedersen, H. C. Secondary metabolite- and endochitinase-dependent antagonism toward plant-pathogenic microfungi of Pseudomonas fluorescensisolates from sugar beet rhizosphere. Appl. Environ. Microbiol.,1998;64: 35633569.

23. Van't Hof., W., Reijnders, I. M., Helmerhorst, E. J. et al. Synergistic effects of low doses of histatin 5 and its analogues on amphotericin B anti-mycotic activity. Antonie Van Leeuwenhoek, 2000;78: 163-9.

24. Lam, YW., Wang, HX., Ng, TB. A robust cysteine-deficient chitinase-like antifungal protein from inner shoots of the edible chive Allium tuberosum. Biochem Biophys Res Commun., 2000; 279(1):74-80.

25. Burianek, L.L., Yousef, A.E. Solvent extraction of bacteriocins from liquid cultures. Let in Appl Microbiol., 2000; 31:193-197.

26. Muriana, PM., Klaenhammer, TR. Purification and partial characterization of lactacin $\mathrm{F}$, a bacteriocin produced by Lactobacillus acidophilus 11088. Appl. Environ. Microbiol., 1991; 57(1):114-121.

27. Vater, J., Kablitz, B., Wilde, C., Franke, P., Mehta, N., Cameotra, S. S. Matrix-assisted laser desorbtion ionizationtime of flight mass spectrometry of lipopeptide biosurfactants in whole cells and culture filtrates of Bacillus subtilis C-1 isolated from petroleum sludge.Appl. Environ. Microbiol., 2002;68: 6210-6219.

28. Stein, T. Bacillus subtilis antibiotics: structure, syntheses and specific functions. Mol Microbiol., 2005; 56:845-857.

29. Budzikiewicz, H. Secondary metabolites from fluorescent pseudomonads. FEMS Microbiol Rev., 1993;104:209-228.

30. Ramette, A., Moënne-Loccoz, Y., Défago, G. Prevalence of fluorescent pseudomonads producing antifungal phloroglucinols and/or hydrogen cyanide in soils naturally suppressive or conducive to tobacco black root rot. FEMS Microbiol Ecol., 2003; 44(1):35-43.

31. Ayyadurai, N., Naik, PR., Sakthivel, N. Functional characterization of antagonistic fluorescent pseudomonads associated with rhizospheric soil of rice (Oryzasativa L.). J Microbiol Biotechnol, 2007;17(6):919-27. 


\section{Indo Global Journal of Pharmaceutical Sciences, 2015; 5(2): 117-123}

32. Ferreira, J.H.S., Matther, F.N., Thomas, A.C. Biological control of Euthypalataon grape vine by an antagonistic strain of Bacillus subtilis. Phytopathology, 1991;81: 283287.

33. Chung et al. Isolation and partial characterization of Bacillus subtilis ME488for suppression of soil borne pathogens of cucumber and pepper. Appl Microbiol Biotechnol, 2008; 80: 115-123.

34. Sadfi, N., Hajaiej, M., Chérif, M., Boudabbous, A. Selection of halophilic Bacillus sp. isolates antagonistic against Fusarium roseum var. sambucinum. Ann. Assoc. Fran. Prot. Plantes, 2000; Vol. II: 615-622.

35. Senthilkumar, A., Kannathasan, K., Venkatesalu, V. Antibacterial activity of the leaf essential oil of Blumeamollis (D. Don) Merr. World J Microbiol Biotechnol., 2009; 25:1297-1300.
36. Cameotra, SS., Makkar, RS. Recent applications of biosurfactants as biological and immunological molecules. Curr Opin Microbiol., 2004; 7:262-266

37. Nitschke, M., Costa, S. G. V. A. O., Haddad, R., Gonc, alves, L. A. G., Eberlin, M. N., Contiero, J. Oil wastes as unconventional substrates for rhamnolipid biosurfactant production by Pseudomonas aeruginosa LBI. Biotechnology Progress, 2005; 21(5): 1562-1566.

38. Daverey, A., Pakshirajan, K. Production, characterization, and properties of sophorolipids from the yeast Candida bombicola using a low-cost fermentative medium. Appl. Biochem. Biotechnol., 2008; 158:663-674.

39. Ahimou, F., Jacques, P. and Deleu, M. Surfactin and iturin A effects on Bacillus subtilis surface hydrophobicity. Enz Microbiol Technol., 2000; 27: 749-754.

40. Ron, E.Z., Rosenberg, E. Natural roles of biosurfactants. Environ Microbiol., 2000; 3: 229-236.

Indo Global Journal of Pharmaceutical Sciences( ISSN 22491023 ; CODEN- IGJPAI; NLM ID: 101610675) indexed and abstracted in EMBASE(Elsevier), SCIRUS(Elsevier),CABI, CAB Abstracts, Chemical Abstract Services(CAS), American Chemical Society(ACS), Index Copernicus, EBSCO, DOAJ, Google Scholar and many more. For further details, visit 